Sains Malaysiana 50(11)(2021): 3231-3239

http://doi.org/10.17576/jsm-2021-5011-07

\title{
Phytochemicals and Bioactivities of Syzygium filiforme var. filiforme
}

\author{
(Fitokimia dan Bioaktiviti Syzygium filiforme var. filiforme)
}

\author{
Mohd Hafiz Ahmad*, Norhazana Nor Izan, Nor Hadiani Ismail \& Humera Naz
}

\begin{abstract}
Syzygium filiforme var. filiforme is a plant variety from dicotyledonous plant family (Myrtaceae). Phytochemical studies on $\mathrm{S}$. filiforme var. filiforme stem bark have successfully isolated and characterized arjunolic acid (1), alphitolic acid (2), betulinic acid (3), ursolic acid (4), ursolic acid 3-methyl ester (5), $\beta$-sitosterol (6) and stigmasterol (7). The inhibitory activities against free radical, starch, and bacteria for major compounds were tested by using DPPH, $\alpha$-glucosidase and minimum inhibitory and bacterial concentration assays, respectively. No promising antioxidant activity was shown on tested samples except methanolic crude extract. For antidiabetic activity, methanolic and dichloromethane crude extracts displayed potent activity compared to 1-deoxynojirimycin. Minimum inhibitory concentration (MIC) and minimum bacterial concentration $(M B C)$ assays for antibacterial activity were evaluated on Escherichia coli, Staphylococcus aureus, and Bacillus subtilis. All crude extracts and major compounds displayed weak and no promising activities for MIC method, respectively. Meanwhile, for MBC method, hexane crude extract and compound 1 showed inhibition against $\mathrm{B}$. subtilis.
\end{abstract}

Keywords: Antibacterial; antidiabetic; antioxidant; Myrtaceae; Syzygium filiforme var. filiforme

\section{ABSTRAK}

Syzygium filiforme var. filiforme adalah varieti tumbuhan daripada keluarga tumbuhan dicotyledonous (Myrtaceae). Kajian fitokimia pada kulit batang S. filiforme var. filiforme berjaya mengasingkan dan mencirikan asid arjunolik (1), asid alfitolik (2), asid betulinik (3), asid ursolik (4), asid ursolik 3-metil ester (5), $\beta$-sitosterol (6) dan stigmasterol (7). Aktiviti penghambatan terhadap radikal bebas, kanji dan bakteria untuk sebatian utama diuji dengan menggunakan DPPH, $\alpha$-glukosidase dan uji kepekatan minimum dan kepekatan bakteria, masing-masing. Tiada aktiviti antioksidan yang menjanjikan pada sampel yang diuji kecuali ekstrak mentah metanolik. Untuk aktiviti antidiabetik, ekstrak mentah metanol dan diklorometana menunjukkan aktiviti yang kuat berbanding dengan 1-deoxynojirimycin. Kaedah kepekatan perencatan minimum (MIC) dan kepekatan bakteria minimum (MBC) untuk aktiviti antibakteria dinilai pada Escherichia coli, Staphylococcus aureus dan Bacillus subtilis. Semua ekstrak mentah dan sebatian utama masing-masing menunjukkan aktiviti lemah dan tidak menjanjikan untuk kaedah MIC. Sementara itu, untuk kaedah MBC, ekstrak mentah heksana dan sebatian 1 menunjukkan perencatan terhadap B. subtilis.

Kata kunci: Antibakteria; antidiabetik; antioksidan; Myrtaceae; Syzygium filiforme var. filiforme

\section{INTRODUCTION}

Syzygium filiforme var. filiforme locally known as 'Kelat' in Malaysia is a variety of S. filiforme (Myrtaceae). It can be found in Australia, Southeast Asia, and South America with concentrations as a big forest tree (Farag et al. 2009; Heng et al. 2013). Since hundred years ago, the Syzygium species is widely used as medicinal plant for treatment of various human diseases. The $S$. samarangense flowers extract has reportedly been used for the treatments of inflammation, asthma, and bronchitis (Minh et al. 2018; Shen et al. 2012; Swadhin et al. 2019). Meanwhile, $S$. cumini have been reported for gastropathy, stomachalgia, spleenopathy, and pharyngitis treatments as well as to strengthen gums and teeth using its seeds and fruits extracts (Ajiboye et al. 2020; Chagas et al. 2015; de Jesus Soares et al. 2019; Kabra \& Patel 2018). Then, the leaf of $S$. cordatum was used as antidiabetic agent in South America and Asia (Cock \& Cheesman 2018; Maliehe et al. 2017; Musabayane et al. 2005). 
The study on chemical constituent from this species provided useful information as sources of bioactive compounds. Triterpenoids are the most common terpenoid compounds contained in Syzygium species and flavonoids are also reported in some species (Babu et al. 2017; Hu et al. 2018; Ito et al. 2004; Saleem et al. 2016). Several types of flavonoids were discovered in this species such as phenols, flavanones, anthocyanins, chalcones, and anthoxanthins (Faria et al. 2011; Gaspar et al. 2020; Manaharan et al. 2012; Nguyen et al. 2016). However, there is no study regarding the biological activity and phytochemical constituents of S. filiforme var. filiforme. Thus, further investigation on the Malaysian $S$. filiforme var. filiforme is recommended to explore their potential as medicinal agent. In this study, we focused on chemical constituents from $S$. filiforme var. filiforme stem bark with their biological properties.

\section{MATERIALS AND METHODS}

\section{SPECTROSCOPIC TECHNIQUES}

The Bruker 500 Ultrashield NMR spectrometer was used to measure ${ }^{1} \mathrm{H}-\mathrm{NMR}$ and ${ }^{13} \mathrm{C}-\mathrm{NMR}$ at 500 and $125 \mathrm{MHz}$, respectively, in deuterated-pyridine, deuterated-methanol or deuterated-chloroform. Chemical shifts and coupling constants were recorded using $\delta$ scale in ppm and $\mathrm{Hz}$, respectively. The hot stage Gallen Kamp melting point apparatus with microscope were used to identify the melting points. Then, the Varian 640 -IR spectrum one FTIR spectrometer $(\mathrm{KBr})$ were used to identify the infrared (IR) spectra. The ultraviolet (UV) and mass spectra were recorded in ethanol on Shimadzu UV-Vis 160i and on TOF LC/MS spectrometer $70 \mathrm{eV}$ (Agilent Technologies 6224), respectively.

\section{PLANT COLLECTION}

The S. filiforme var. filiforme was identified by Dr. Shamsul Khamis from Universiti Putra Malaysia (UPM). The plant stem bark (UiTM 14/2009) was collected from Pasir Raja, Terengganu and deposited at Herbarium Faculty of Applied Sciences, Universiti Teknologi MARA Malaysia, Shah Alam. It was air dried and grounded into fine powder.

\section{FRACTIONATION AND ISOLATION OF COMPOUNDS}

The step gradient polarity solvents (hexane, dichloromethane and methanol) were used to extract successively the chemical constituents from $3 \mathrm{~kg}$ of stem bark plant sample ( $72 \mathrm{~h}$, three times, $10 \mathrm{~L})$. Then, the crude extracts were evaporated until dryness under reduced pressure using rotary evaporator. About 7 fractions were yielded using vacuum liquid chromatography (VLC) from methanolic crude extract $(60.3 \mathrm{~g})$. From methanol extract, three compounds were obtained 1 (58.7 mg), $2(18.7 \mathrm{mg})$ and $3(22.6 \mathrm{mg})$. Meanwhile, 4 (8.1 mg), 5 (1.5 mg), 6 (4.2 $\mathrm{mg})$ and 7 (3.9 $\mathrm{mg})$ were obtained from dichloromethane extract. The structure of isolated compounds was characterized using infrared spectroscopy (IR), mass spectrometry (MS) and nuclear magnetic resonance spectroscopy (NMR).

\section{SPECTRAL DATA}

\section{Compound 1}

Weight: $58.7 \mathrm{mg}$, white amorphous solid, melting point: 292-295 ${ }^{\circ} \mathrm{C}$. UV (MeOH) $\lambda_{\max }=218 \mathrm{~nm}$. IR cm $\mathrm{cm}^{-1}: 3401$, 2944, 2857, 1694, 1462, 1390. MS m/z: 487.3 [M-H]', $\mathrm{C}_{30} \mathrm{H}_{48} \mathrm{O}_{5} \cdot{ }^{1} \mathrm{H}$ and ${ }^{13} \mathrm{C}$ NMR were similar with published data (Djoukeng et al. 2005).

\section{Compound 2}

Weight: $18.7 \mathrm{mg}$, white amorphous solid, melting point: 274-277 ${ }^{\circ} \mathrm{C}$. UV (MeOH) $\lambda_{\max }=207 \mathrm{~nm}$. IR cm ${ }^{-1}: 3435$, 2942, 2868, 1692, 1454, 1376. MS m/z: 471.3 [M-H]', $\mathrm{C}_{30} \mathrm{H}_{48} \mathrm{O}_{4} \cdot{ }^{1} \mathrm{H}$ and ${ }^{13} \mathrm{C}$ NMR were similar with published data (Bai et al. 2015).

\section{Compound 3}

Weight: $22.6 \mathrm{mg}$, white amorphous solid, melting point: 314-317 ${ }^{\circ} \mathrm{C}$. UV (MeOH) $\lambda_{\max }=197 \mathrm{~nm}$. IR cm ${ }^{-1}: 3467$, 2943, 2862, 1687, 1452, 1376. MS m/z: 455.2 [M-H]', $\mathrm{C}_{30} \mathrm{H}_{48} \mathrm{O}_{3} .{ }^{1} \mathrm{H}$ and ${ }^{13} \mathrm{C}$ NMR were similar with published data (Kuiate et al. 2007).

\section{Compound 4}

Weight: $8.1 \mathrm{mg}$, white amorphous solid, melting point: 283-286 ${ }^{\circ} \mathrm{C}$. UV (MeOH) $\lambda_{\text {max }}=212 \mathrm{~nm}$. IR cm ${ }^{-1}: 3429$, 2924, 2851, 1688, 1463. MS $m / z$ : $455.2[\mathrm{M}-\mathrm{H}]^{-}, \mathrm{C}_{30} \mathrm{H}_{48} \mathrm{O}_{3}$. ${ }^{1} \mathrm{H}$ and ${ }^{13} \mathrm{C}$ NMR were similar with published data (Ismail et al. 2010).

\section{Compound $\mathbf{5}$}

Weight: $1.5 \mathrm{mg}$, white amorphous solid, melting point: 170-174 ${ }^{\circ} \mathrm{C}$. UV (MeOH) $\lambda_{\max }=218 \mathrm{~nm}$. MS $m / z: 471.3$ $[\mathrm{M}+\mathrm{H}]^{+}, \mathrm{C}_{31} \mathrm{H}_{49} \mathrm{O}_{3} \cdot{ }^{1} \mathrm{H}$ and ${ }^{13} \mathrm{C}$ NMR were similar with published data (Kim et al. 2005).

\section{Compound 6}

Weight: $4.2 \mathrm{mg}$, white amorphous solid, melting point: 133-136 ${ }^{\circ} \mathrm{C}$. MS $m / z: 413.1[\mathrm{M}-\mathrm{H}]-\mathrm{C}_{29} \mathrm{H}_{50} \mathrm{O} .{ }^{1} \mathrm{H}$ and ${ }^{13} \mathrm{C}$ 
NMR were similar with published data (Güvenalp et al. 2006).

\section{Compound 7}

Weight: $3.9 \mathrm{mg}$, white amorphous solid, melting point: 176-179 ${ }^{\circ} \mathrm{C}$. MS $m / z$ : $413.1[\mathrm{M}+\mathrm{H}]^{+}, \mathrm{C}_{29} \mathrm{H}_{48} \mathrm{O} .{ }^{1} \mathrm{H}$ and ${ }^{13} \mathrm{C}$ NMR were similar with published data (De-Eknamkul \& Potduang 2003).

\section{DPPH ASSAY}

Detailed procedure explained below as reported by Teoh et al. (2013). The $50 \mu \mathrm{L}$ of samples were dissolved and diluted in different concentration from 5, 10, 20, 40, 60,80 , and $100 \mu \mathrm{g} / \mathrm{mL}$. Then, ascorbic acid was used as positive control. The following equation was used to calculate the percentage of DPPH scavenging effect of antioxidant activity:

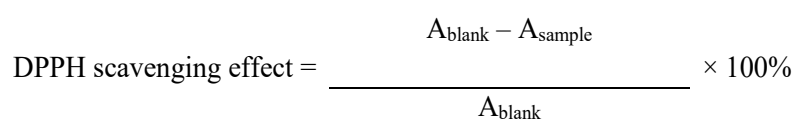

A is denoted as the absorbance of tested mixture samples measured at $517 \mathrm{~nm}$. The experiments were conducted in triplicate.

\section{ANTIDIABETIC ASSAY}

The antidiabetic properties of tested samples were conducted using in vitro $\alpha$-glucosidase assay protocol reported by Lee et al. (2008). About $1 \mathrm{mg} / \mathrm{mL}$ concentration of samples and standard 1-deoxynojirimycin were prepared in $5 \%$ of DMSO. The concentration of 0.69 to $1 \mathrm{mg} / \mathrm{mL}$ was prepared by two foil serial dilutions. The following equation was used to identify the inhibition rate $(\%)$ of antidiabetic activity:

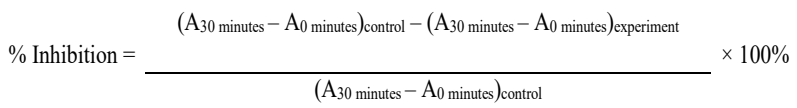

A is denoted as the absorbance of tested mixture samples measured at $405 \mathrm{~nm}$.

\section{ANTIBACTERIAL ASSAY}

The minimum inhibitory concentration (MIC) and minimum bacterial concentration (MBC) of samples were carried out based on previous protocol (Zakaria et al. 2010) on Escherichia coli, Staphylococcus aureus, and Bacillus subtilis. Around $100 \mu \mathrm{L}$ of samples were mixed with $50 \mu \mathrm{L}$ of broth and gentamycin was used as positive control. The different concentration of samples (28.13 to $1800 \mu \mathrm{g} / \mathrm{mL}$ ) were mixed with microorganism previously inoculated and cultured for $24 \mathrm{~h}$ in microtiter plate by serial dilutions and were incubated for $24 \mathrm{~h}$ at temperature $37{ }^{\circ} \mathrm{C}$. Then, the samples mixture in well plate was mixed with $20 \mu \mathrm{L}$ of MTT solution after $24 \mathrm{~h}$ and was incubated again for $20 \mathrm{~min}$. The results were measured at $620 \mathrm{~nm}$ using multi-well scanning spectrophotometer (ELISA reader).

\section{RESULTS AND DISCUSSION}

In this study, we have successfully isolated seven compounds from S. filiforme var. filiforme stem bark (Myrtaceae) as shown in Figure 1. Arjunolic acid (1) was classified as oleanane type. Then, alphitolic acid (2) and betulinic acid (3) were identified as lupane type. The ursane type is ursolic acid (4) and ursolic acid 3-methyl ester (5). Meanwhile, $\beta$-sitosterol (6) and stigmasterol (7) were classified as phytosterol type of triterpenoids. The IR, LCMS, 1D NMR $\left({ }^{1} \mathrm{H},{ }^{13} \mathrm{C}\right.$, DEPTQ NMR) and 2D NMR (HMQC, HMBC, COSY, NOESY) techniques were used to characterize the structure of isolated compounds.

Compound 1 appeared as white amorphous solid with a melting point $292-295{ }^{\circ} \mathrm{C}$ and was isolated from methanolic crude extract. Its spectral data has similarity with arjunolic acid isolated from $S$. guineense (Myrtaceae) (Djoukeng et al. 2005). Two lupane type triterpenoids, compounds $\mathbf{2}$ and $\mathbf{3}$ were also isolated from methanolic crude extract. Compound $\mathbf{2}$ was isolated as white amorphous solid with a melting point $274-277^{\circ} \mathrm{C}$ and its spectral data has compared with literature value (Bai et al. 2015) and confirmed that the compound $\mathbf{2}$ is alphitolic acid. Meanwhile, compound $\mathbf{3}$ was appeared as white amorphous solid with a melting point $314-317$ ${ }^{\circ} \mathrm{C}$ and identified as betulinic acid previously isolated from the stem bark of $S$. jambos (L.) Alston (Myrtaceae) (Kuiate et al. 2007).

Two ursane type triterpenoids, compounds 4 and $\mathbf{5}$ were isolated as white amorphous solid with melting point $283-286^{\circ} \mathrm{C}$ and $170-174{ }^{\circ} \mathrm{C}$, respectively, from dichloromethane extract. It was reported that compound $\mathbf{4}$ was previously contained in $S$. malaccense leaves extract (Myrtaceae) (Ismail et al. 2010) while compound $\mathbf{5}$ from Campsis grandiflora flower extract (Bignoniaceae) (Kim et al. 2005). Furthermore, compounds 6 and 7 were obtained as white amorphous solid with melting point $133-136{ }^{\circ} \mathrm{C}$ and $176-179{ }^{\circ} \mathrm{C}$, respectively, from dichloromethane extract. They are classified as well-known phytosterols and easily found in most of the medicinal plants. 


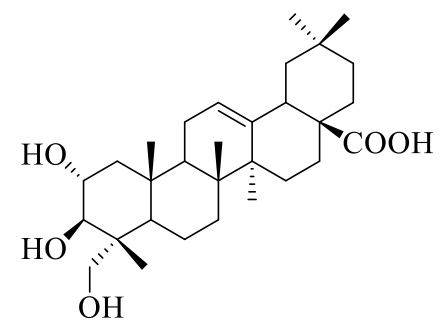

1

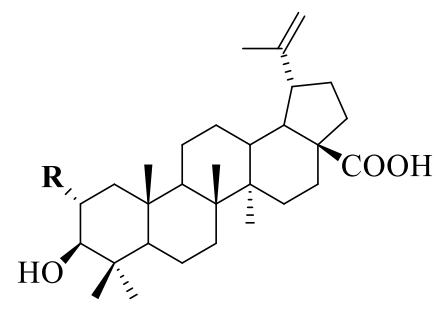

R

2: H

3: $\mathrm{OH}$

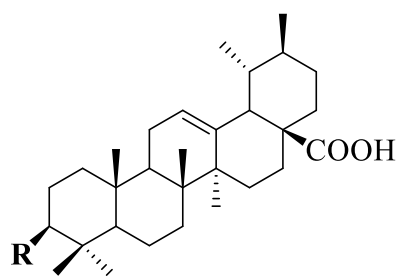

R

4: $\mathrm{OH}$

5: $\mathrm{OCH}_{3}$<smiles>CCC(CC[C@@H](C)C1CCC2C3CC=C4CC(O)CCC4(C)C3CCC21C)C(C)C</smiles>

6<smiles>CCC(C=CC(C)C1CCC2C3CC=C4CC(O)CCC4(C)C3CCC12C)C(C)C</smiles>

7

FIGURE 1. Isolated compounds from Syzygium filiforme var. filiforme. $2 \alpha, 3 \beta$, 23-trihydroxyolean-12-en-28-

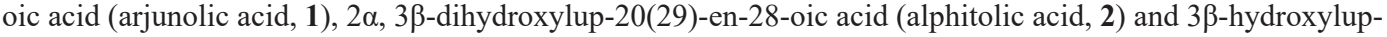
20(29)-en-28-oic acid (betulinic acid, 3), 33-hydroxyurs-12-en-28-oic acid (ursolic acid, 4) and ursolic acid 3-methyl ester (5), $\beta$-sitosterol (6) and stigmasterol (7) 
The radical scavenging activity for tested samples was identified by the different in percentage inhibition towards free radicals. The potential of each samples was observe using the established protocol for DPPH assay. Moreover, the greater activity was observed with the lowest $\mathrm{IC}_{50}$ values (Banerjee et al. 2005). The sample concentration required to inhibit $50 \%$ of free radicals is known as $\mathrm{IC}_{50}$ value. The tested samples with final concentrations of $5,10,20,40,60,80$, and $100 \mu \mathrm{g} / \mathrm{mL}$ were used to evaluate the antioxidant activity of tested samples.

Table 1 shows the radical scavenging activity of tested samples with their $\mathrm{IC}_{50}$ values compared with standard ascorbic acid. Among all tested samples, methanolic crude extract demonstrated the good potential as radical scavenger with $\mathrm{IC}_{50}$ value of $44.7 \pm 6.42 \mu \mathrm{g} / \mathrm{mL}$. Similar result was obtained with study on methanolic crude extract from leaf of S. malaccense (L.) Merr and Perr which has antiradical effect with $\mathrm{IC}_{50}$ value of $25.74 \pm 0.0 \mu \mathrm{g} / \mathrm{mL}$ (Savitha et al. 2011). It is also similar with methanolic crude extract of S. jambos, S. javanicum, S. samarangense, and $S$. curranii which has promising antioxidant activity with $\mathrm{IC}_{50}$ values $92.0 \pm 8.24,81.4 \pm 6.24,77.5 \pm 4.19$, and $33.4 \pm 2.52 \mu \mathrm{g} / \mathrm{mL}$, respectively (Reynertson et al. 2008). Finally, dichloromethane and hexane crude extracts as well as major compounds showed no promising antioxidant properties towards DPPH radicals.

TABLE 1. The $\mathrm{IC}_{50}$ values of $S$. filiforme var. filiforme crude

extracts, major compounds and ascorbic acid

\begin{tabular}{lc}
\hline Sample & $\mathrm{IC}_{50}(\mu \mathrm{g} / \mathrm{mL})$ \\
\hline MeOH crude extract & $44.7 \pm 6.42$ \\
DCM crude extract & $\mathrm{NA}$ \\
Hexane crude extract & $\mathrm{NA}$ \\
Arjunolic acid & $\mathrm{NA}$ \\
Betulinic acid & $\mathrm{NA}$ \\
Alphitolic acid & $\mathrm{NA}$ \\
Ursolic acid & $\mathrm{NA}$ \\
Ascorbic acid & $7.9 \pm 1.20$ \\
\hline
\end{tabular}

The $\alpha$-glucosidase activity of tested samples is displayed in Table 2 with their $\mathrm{IC}_{50}$ values compared with standard 1-deoxynojirimycin. The samples stock solution $(1 \mathrm{mg} /$
$\mathrm{mL}$ ) of tested samples was diluted to final concentrations 69.3 to $1000 \mu \mathrm{g} / \mathrm{mL}$ for evaluation of their antidiabetic properties.

TABLE 2. The $\mathrm{IC}_{50}$ values of $S$. filiforme var. filiforme crude extracts, major compounds and 1-deoxynojirimycin

\begin{tabular}{ll}
\hline Sample & $\mathrm{IC}_{50}(\mu \mathrm{g} / \mathrm{mL})$ \\
\hline MeOH extract & $6.31 \pm 0.90$ \\
DCM extract & $100 \pm 9.90$ \\
Hexane extract & $\mathrm{NA}$ \\
Arjunolic acid & $562.34 \pm 11.80$ \\
Betulinic acid & $501.19 \pm 8.20$ \\
Alphitolic acid & $\mathrm{NA}$ \\
Ursolic acid & $\mathrm{NA}$ \\
1-deoxynojirimycin & $103.79 \pm 6.36$ \\
\hline
\end{tabular}


Methanolic $\left(\mathrm{IC}_{50}=6.31 \pm 0.90 \mu \mathrm{g} / \mathrm{mL}\right)$ and dichloromethane $\left(\mathrm{IC}_{50}=100 \pm 0.90 \mu \mathrm{g} / \mathrm{mL}\right)$ crude extracts displayed promising antidiabetic effect compared to 1-deoxynojirimycin. It can be noted that most of crude extracts showed great potential to convert carbohydrates into monosaccharide. This is similar with butanolic crude extract of $S$. cumini seed kernels which showed good antidiabetic activity with $\mathrm{IC}_{50}$ value of $8.3 \pm 0.2 \mu \mathrm{g} /$ $\mathrm{mL}$ compared to standard 1-deoxynojirimycin (Shinde et al. 2008). Radical scavenging effect of compounds 1 and 3 indicated promising antidiabetic activity with $\mathrm{IC}_{50}$ values of $562.34 \pm 11.80$ and $501.19 \pm 8.20 \mu \mathrm{g} / \mathrm{mL}$, respectively. Then, no promising activity was identified for the other samples.
Antibacterial activity for tested samples were carried out using minimum inhibitory concentration (MIC) technique with final concentrations of 28.13 to $1800 \mu \mathrm{g} /$ $\mathrm{mL}$ against $E$. coli, S. aureus, and B. subtilis as shown in Table 3. All crude extracts showed antibacterial activity against tested bacteria except dichloromethane extract. Hexane crude extract at highest concentration demonstrated more potential while methanolic crude extract displayed antibacterial activity against $S$. aureus with $\mathrm{IC}_{50}$ value of $900 \mu \mathrm{g} / \mathrm{mL}$. Similar results were observed with study on leaves crude extracts of S. cumini which showed antibacterial effect against E. coli, $S$. aureus, and B. subtilis (Ugbabe et al. 2010).

TABLE 3. The minimum inhibitory concentration (MIC) of S. filiforme var. filiforme crude extracts, major compounds and gentamycin

\begin{tabular}{llll}
\hline Sample & E. coli $(\mu \mathrm{g} / \mathrm{mL})$ & S. aureus $(\mu \mathrm{g} / \mathrm{mL})$ & B. subtilis $(\mu \mathrm{g} / \mathrm{mL})$ \\
\hline MeOH extract & NA & 900 & NA \\
DCM extract & NA & NA & NA \\
Hexane extract & 1800 & 900 & 1800 \\
Arjunolic acid & 1800 & 450 & 900 \\
Alphitolic acid & NA & 900 & NA \\
Betulinic acid & NA & NA & NA \\
Ursolic acid & 1800 & NA & NA \\
Gentamycin & 28.13 & 28.13 & 28.13 \\
\hline
\end{tabular}

Two major compounds, compounds $\mathbf{1}$ and $\mathbf{2}$ showed inhibition against $S$. aureus with MIC values of 450 and $900 \mu \mathrm{g} / \mathrm{mL}$, respectively. Interestingly, compound $\mathbf{1}$ is also showed antibacterial effect against $E$. coli and $B$. subtilis at highest concentration. Meanwhile, compound 4 at highest concentration demonstrated antibacterial activity against $E$. coli but compound $\mathbf{3}$ showed no inhibition against tested bacteria. Based on literature, compounds $\mathbf{3}$ and $\mathbf{4}$ at highest concentration displayed mild antibacterial effect against E. coli and B. subtilis (Chandramu et al. 2003).

The minimum bacterial concentration (MBC) of crude extracts and major compounds compared to standard gentamycin is displayed in Table 4. Hexane crude extract, compounds $\mathbf{1}$ and $\mathbf{4}$ showed promising antibacterial effect against $E$. coli with MBC values of $1800 \mu \mathrm{g} / \mathrm{mL}$ equivalent to their MIC values. Meanwhile, the MBC values of methanolic and hexane crude extracts against $S$. aureus were determined at concentration 1000 and 1100 $\mu \mathrm{g} / \mathrm{mL}$, respectively. On the other hand, the MBC values of compounds $1(560 \mu \mathrm{g} / \mathrm{mL})$ and $\mathbf{2}(1000 \mu \mathrm{g} / \mathrm{mL})$ on the same bacteria showed higher than their MIC values. Finally, all tested samples displayed no inhibition against B. subtilis except hexane crude extract and compound $\mathbf{1}$ with $\mathrm{MBC}$ values 1800 and $1100 \mu \mathrm{g} / \mathrm{mL}$, respectively. 
TABLE 4. The minimum bactericidal concentration (MBC) of S. filiforme var. filiforme crude extracts, major compounds and gentamycin

\begin{tabular}{lccc}
\hline Sample & E. coli $(\mu \mathrm{g} / \mathrm{mL})$ & S. aureus $(\mu \mathrm{g} / \mathrm{mL})$ & B. subtilis $(\mu \mathrm{g} / \mathrm{mL})$ \\
\hline MeOH extract & NA & 1000 & NA \\
DCM extract & NA & NA & NA \\
Hexane extract & 1800 & 1100 & 1800 \\
Arjunolic acid & 1800 & 560 & 1100 \\
Alphitolic acid & NA & 1000 & NA \\
Betulinic acid & NA & NA & NA \\
Ursolic acid & 1800 & NA & NA \\
Gentamycin & 28.13 & 28.13 & 28.13 \\
\hline
\end{tabular}

\section{CONCLUSION}

Methanol and dichloromethane extracts showed potent antidiabetic activity compared to 1-deoxynojirimycin using $\alpha$-glucosidase assay. This might be due to the traditional uses of Syzygium species as antidiabetic for old folks. For antibacterial activity, to the MBC values of hexane extract, compounds $\mathbf{1}$ and $\mathbf{4}$ against $E$. coli were equivalent to MIC values $1800 \mu \mathrm{g} / \mathrm{mL}$. Methanol extract, hexane extract, compounds $\mathbf{1}$ and $\mathbf{2}$ showed activity on $S$. aureus with MBC values of 1000,1100 , 560 , and $1000 \mu \mathrm{g} / \mathrm{mL}$, respectively, higher than MIC values against same bacteria. Then, all samples have no promising activity against $B$. subtilis except hexane extract and compound 1 with MBC values 1800 and $1100 \mu \mathrm{g} / \mathrm{mL}$, respectively. Finally, the $S$. filiforme var. filiforme species could become potential as antidiabetic and medicinal agent for drug discovery.

\section{ACKNOWLEDGEMENTS}

The authors would like to acknowledge Universiti Teknologi MARA for research grants No. 600-600IRMI 5/3/LESTARI (025/2019). The authors declare that the research was conducted in the absence of any commercial or financial relationships that could be construed as a potential conflict of interest.

\section{REFERENCES}

Ajiboye, B.O., Ojo, O.A., Oyinloye, B.E., Akuboh, O., Okesola, M.A., Idowu, O. \& Kappo, A.P. 2020. In vitro antioxidant and inhibitory activities of polyphenolic-rich extracts of Syzygium cumini (Linn) Skeels leaf on two important enzymes relevant to type II diabetes mellitus. Pakistan Journal of Pharmaceutical Sciences 33(2): 523-529.

Babu, T.M.C., Rajesh, S.S., Bhaskar, B.V., Devi, S., Rammohan, A., Sivaraman, T. \& Rajendra, W. 2017. Molecular docking, molecular dynamics simulation, biological evaluation and 2D QSAR analysis of flavonoids from Syzygium alternifolium as potent anti-Helicobacter pylori agents. The Royal Society of Chemistry Advances 7(30): 18277 18292.

Bai, L.Y., Chiu, C.F., Chiu, S.J., Chen, Y.W., Hu, J.L., Wu, C.Y. \& Weng, J.R. 2015. Alphitolic acid, an anti-inflammatory triterpene, induces apoptosis and autophagy in oral squamous cell carcinoma cells, in part, through a p53dependent pathway. Journal of Functional Foods 18: 368378.

Banerjee, A., Dasgupta, N. \& De, B. 2005. In vitro study of antioxidant activity of Syzygium cumini fruit. Food Chemistry 90(4): 727-733.

Chagas, V.T., França, L.M., Malik, S. \& Paes, A.M.d.A. 2015. Syzygium cumini (L.) skeels: A prominent source of bioactive molecules against cardiometabolic diseases. Frontiers in Pharmacology 6: 259-259.

Chandramu, C., Manohar, R.D., Krupadanam, D.G. \& Dashavantha, R.V. 2003. Isolation, characterization and biological activity of betulinic acid and ursolic acid from Vitex negundo L. Phytotherapy Research: An International Journal Devoted to Pharmacological and Toxicological Evaluation of Natural Product Derivatives 17(2): 129-134.

Cock, I.E. \& Cheesman, M. 2018. Plants of the genus Syzygium (Myrtaceae): A review on ethnobotany, medicinal properties and phytochemistry. In Bioactive Compounds 
of Medicinal Plants: Properties and Potential for Human Health, edited by Goyal, M.R. \& Ayeleso, A. Florida: Apple Academic Press. pp. 35-84.

De Jesus Soares, J., da Silva Rosa, A., Motta, P.R., Cibin, F.W.S., Roehrs, R. \& Denardin, E.L.G. 2019. Protective role of Syzygium cumini leaf extracts against paraquatinduced oxidative stress in superoxide-dismutase-deficient Saccharomyces cerevisiae strains. Acta Scientiarum Biological Sciences 41: e47139-e47139.

De-Eknamkul, W. \& Potduang, B. 2003. Biosynthesis of $\beta$-sitosterol and stigmasterol in Croton sublyratus proceeds via a mixed origin of isoprene units. Phytochemistry 62(3): 389-398.

Djoukeng, J.D., Abou-Mansour, E., Tabacchi, R., Tapondjou, A.L., Bouda, H. \& Lontsi, D. 2005. Antibacterial triterpenes from Syzygium guineense (Myrtaceae). Journal of Ethnopharmacology 101(1-3): 283-286.

Farag, F., Sasse, F., Hendrarto, B. \& Izzati, M. 2009. Tree species composition and distribution in Sungai Lalang Forest Reserve, Selangor, Malaysia. The 10th International Seminar on Environment and Architecture 12(1): 29-34.

Faria, A.F., Marques, M.C. \& Mercadante, A.Z. 2011. Identification of bioactive compounds from jambolao (Syzygium cumini) and antioxidant capacity evaluation in different pH conditions. Food Chemistry 126(4): 15711578.

Gaspar, R.S., da Silva, S.A., Stapleton, J., Fontelles, J.L.d.L., Sousa, H.R., Chagas, V.T., Alsufyani, S., Trostchansky, A., Gibbins, J.M. \& Paes, A.M.d.A. 2020. Myricetin, the main flavonoid in Syzygium cumini leaf, is a novel inhibitor of platelet thiol isomerases PDI and ERp5. Frontiers in Pharmacology 10: 1678.

Güvenalp, Z., Kilic, N., Kazaz, C., Kaya, Y. \& Demirezer, L.Ö. 2006. Chemical constituents of Galium tortumense. Turkish Journal of Chemistry 30(4): 515-523.

Heng, R.K.J., Majid, N., Gandaseca, S. \& Ahmed, O. 2013. Assessment of floristic composition in a rehabilitated forest, Sarawak, Malaysia. Borneo Journal of Resource Science and Technology 2: 60-66.

Hu, Y.K., Wang, L., Li, Y.Y., Li, M.J., Xu, W., Zhao, Y., Li, F. \& Zhao, Y. 2018. Five new triterpenoids from Syzygium samarangense (B1.) Merr. et Perry. Phytochemistry Letters 25: 147-151.

Ismail, I.S., Ismail, N. \& Lajis, N. 2010. Ichthyotoxic properties and essential oils of Syzygium malaccense (Myrtaceae). Pertanika Journal of Science \& Technology 18(1): 1-6.

Ito, H., Iwamori, H., Kasajima, N., Kaneda, M. \& Yoshida, T. 2004. Kunzeanones A, B, and C: novel alkylated phloroglucinol metabolites from Kunzea ambigua. Tetrahedron 60(44): 9971-9976.

Kabra, S. \& Patel, S. 2018. Total phenolics \& flavonoid content of the leaves of Carica papaya \& Syzygium cumini. World Journal of Pharmaceutical Research 7(14): 734-741.
Kim, D.H., Han, K.M., Chung, I.S., Kim, D.K., Kim, S.H., Kwon, B.M., Jeong, T.S., Park, M.H., Ahn, E.M. \& Baek, N.I. 2005. Triterpenoids from the flower of Campsis grandiflora K. Schum. as human acyl-CoA: Cholesterol acyltransferase inhibitors. Archives of Pharmacal Research 28(5): 550-556.

Kuiate, J.R., Mouokeu, S., Wabo, H.K. \& Tane, P. 2007. Antidermatophytic triterpenoids from Syzygium jambos (L.) Alston (Myrtaceae). Phytotherapy Research: An International Journal Devoted to Pharmacological and Toxicological Evaluation of Natural Product Derivatives 21(2): 149-152.

Lee, S.S., Lin, H.C. \& Chen, C.K. 2008. Acylated flavonol monorhamnosides, $\alpha$-glucosidase inhibitors, from Machilus philippinensis. Phytochemistry 69(12): 2347-2353.

Maliehe, T.S., Shandu, J.S., Basson, A.K., Simelane, M.B., Lazarus, G. \& Singh, M. 2017. Pharmacodynamic and cytotoxicity effects of Syzygium cordatum \{S Ncik, 48 (UZ) \} fruit-pulp extract in gastrointestinal tract infections. Tropical Journal of Pharmaceutical Research 16(6): 13491355.

Manaharan, T., Appleton, D., Cheng, H.M. \& Palanisamy, U.D. 2012. Flavonoids isolated from Syzygium aqueum leaf extract as potential antihyperglycaemic agents. Food Chemistry 132(4): 1802-1807.

Minh, N.P., Anh, N.H., Pha, P.T.L. \& Bach, L.G. 2018. Effect of blanching, drying and preservation of dried wax apple (Syzygium samarangense) leaf tea. Research on Crops 19(4): 730-735.

Musabayane, C.T., Mahlalela, N., Shode, F.O. \& Ojewole, J.A. 2005. Effects of Syzygium cordatum (Hochst.) [Myrtaceae] leaf extract on plasma glucose and hepatic glycogen in streptozotocin-induced diabetic rats. Journal of Ethnopharmacology 97(3): 485-490.

Nguyen, T.L., Rusten, A., Bugge, M.S., Malterud, K.E., Diallo, D., Paulsen, B.S. \& Wangensteen, H. 2016. Flavonoids, gallotannins and ellagitannins in Syzygium guineense and the traditional use among Malian healers. Journal of Ethnopharmacology 192: 450-458.

Reynertson, K.A., Yang, H., Jiang, B., Basile, M.J. \& Kennelly, E.J. 2008. Quantitative analysis of antiradical phenolic constituents from fourteen edible Myrtaceae fruits. Food Chemistry 109(4): 883-890.

Saleem, U., Ali, N. \& Ahmad, B. 2016. Does Syzygium cumini possess significant pharmacological effects an overview. Newsletter 2: 26-29.

Savitha, R.C., Padmavathy, S. \& Sundhararajan, A. 2011. In vitro antioxidant activities on leaf extracts of Syzygium malaccense (L.) merr and perry. Ancient Science of Life 30(4): 110-113.

Shen, S.C., Chang, W.C. \& Chang, C.L. 2012. Fraction from wax apple [Syzygium samarangense (Blume) Merrill and Perry] fruit extract ameliorates insulin resistance via modulating 
insulin signaling and inflammation pathway in tumor necrosis factor $\alpha$-treated FL83B mouse hepatocytes. International Journal of Molecular Sciences 13(7): 8562-8577.

Shinde, J., Taldone, T., Barletta, M., Kunaparaju, N., Hu, B., Kumar, S., Placido, J. \& Zito, S.W. 2008. $\alpha$-Glucosidase inhibitory activity of Syzygium cumini (Linn.) Skeels seed kernel in vitro and in Goto-Kakizaki (GK) rats. Carbohydrate Research 343(7): 1278-1281.

Swadhin, T.H., Islam, M.M. \& Lima, K.A. 2019. Effect of different concentration of (Indole 3-Butyric Acid) on stem cutting of jamrul (Syzygium samarangense) at Patuakhali District under Dumki Upazila. Asian Journal of Research and Review in Agriculture 1(1): 36-44.

Teoh, W.Y., Sim, K.S., Richardson, M., Stella, J., Abdul Wahab, N. \& Hoe, S.Z. 2013. Antioxidant capacity, cytotoxicity, and acute oral toxicity of Gynura bicolor. Evidence-Based Complementary and Alternative Medicine 2013: 1-10.

Ugbabe, G., Ezeunala, M., Edmond, I., Apev, J. \& Salawu, O. 2010. Preliminary phytochemical, antimicrobial and acute toxicity studies of the stem, bark and the leaves of a cultivated Syzygium cumini Linn. (Family: Myrtaceae) in Nigeria. African Journal of Biotechnology 9(41): 6943-6747.

Zakaria, Z., Sufian, A., Ramasamy, K., Ahmat, N., Sulaiman, M., Arifah, A., Zuraini, A. \& Somchit, M. 2010. In vitro antimicrobial activity of Muntingia calabura extracts and fractions. African Journal of Microbiology Research 4(4): 304-308.
Mohd Hafiz Ahmad*

Nanotechnology \& Catalysis Research Centre (NANOCAT)

University of Malaya, Block 3A

Inst. of Graduate Studies Building

50603 Kuala Lumpur, Federal Territory

Malaysia

Norhazana Nor Izan

Faculty of Applied Sciences

Universiti Teknologi MARA

40450 Shah Alam, Selangor Darul Ehsan

Malaysia

Mohd Hafiz Ahmad* \& Nor Hadiani Ismail

Atta-ur-Rahman Institute for Natural Produtcs Discovery

(AuRIns)

Universiti Teknologi MARA, Puncak Alam Campus

42300 Bandar Puncak Alam, Selangor Darul Ehsan

Malaysia

Humera Naz

Faculty of Pharmacy

Universiti Teknologi MARA, Puncak Alam Campus 42300 Bandar Puncak Alam, Selangor Darul Ehsan Malaysia

*Corresponding author; email: hafiz99414@yahoo.com

Received: 3 May 2020

Accepted: 17 March 2021 